\title{
Rekreasyon Faaliyetlerine Katılan Kişilerin (Rekreasyonistlerin) Örtük Liderlik Algiları
}

\author{
Implicit Leadership Perceptions of People (Recreationists) Who Participate in Recreation Activities
}

\author{
Meryem AKOĞLAN KOZAK*, Çağdaş AYDIN**, Ceren AYDIN*** \\ * Prof. Dr., Anadolu Üniversitesi, İşletme Fakültesi, Yunus Emre Kampüsü, 26470, Tepebaşı, Eskişehir. \\ E-posta:mkozak@anadolu.edu.tr \\ ORCID: 0000-0003-0577-1843 \\ **Araş. Gör., Anadolu Üniversitesi, Sosyal Bilimler Enstitüsü, Yunus Emre Kampüsü, 26470, Tepebaşı, Eskişehir. \\ E-posta: cagdasaydin@anadolu.edu.tr \\ ORCID: 0000-0003-3194-4218 \\ ***Doktora Öğrencisi, Anadolu Üniversitesi, Sosyal Bilimler Enstitüsü, Turizm İşletmeciliği Ana Bilim Dalı, Yunus Emre Kampüsü, 26470, Tepebaşı, Eskişehir. \\ E-posta: cerendiktas@anadolu.edu.tr \\ ORCID: 0000-0001-8325-5743
}

MAKALE BILGILERI

Makale işlem bilgileri:

Gönderilme tarihi: 17 Kasım 2016

Düzeltme: 17 Ocak 2017

Düzeltme: 14 Şubat 2017

Kabul: 17 Şubat 2017

Anahtar sözcükler: Liderlik, Örtük liderlik, Rekreasyon, Rekreasyonel liderlik, Rekreasyonist.

\section{ARTICLE INFO}

Article history:

Submitted: 17 November 2016

Resubmitted: 17 January 2017

Resubmitted: 14 February 2017

Accepted: 17 February 2017

Key words: Leadership, Implicit leadership, Recreation, Recreational leadership, Recreationalist.

\begin{abstract}
ÖZ
Bu çalıșmada, farklı rekreasyon aktivitelerine katılan rekreasyonistlerin örtük liderlikle ilgili algılarının belirlenmesine çalışılmaktadır. Çalışmanın sonuçları, rekreasyon aktivitelerinde liderlik yapan bireylerin, rekreasyonistlerin beklentileri doğrultusunda liderlik sürecini planlayabilmeleri açısından önemlidir. Nicel araştırma yönteminin kullanıldığı bu çalıșmada, veriler anket aracılığıyla toplanmıștır. Veriler, 05.07.2016 ile 20.10.2016 tarihleri arasında "rekreasyon" ve "bos zaman" ismiyle olușturulan sosyal medya gruplarından anket tekniği ile elde edilmiştir. Verilerin analiz edilmesinde, faktör analizi, tek yönlü varyans analizi ve T testinden yararlanıımıştır. Örtük liderlik algısına yönelik faktörlerin belirlenmesinde alanyazından sağlanan; beceriklilik, duyarlılık, kișisel ahlak ve güc faktörleri kullanılmıștır. Örtük liderlikte, bașta beceriklilik faktörü olmak üzere sırasıyla duygusallık, kişisel ahlak ve güç faktörlerinin önemli olduğu belirlenmiştir. Ayrıca, açık ve kapalı alan aktivitelerine katılan rekreasyonistlerin beceriklilik, duyarlılık ve kişisel ahlak faktörlerinde, kadın ve erkek rekreasyonistlerin beceriklilik, kişisel ahlak ve güç faktörlerinde ve eğitim durumuna göre rekreasyonistlerin ise beceriklilik, duyarlılık ve güç faktörlerinde farklılaștığı gözlenmiştir.
\end{abstract}

\section{GíRiş}

Günümüzde kişilerin artan boş zamanlarına ve rekreasyon aktivitelerine yönelik talebine bağlı olarak çeşitli rekreasyon organizasyonları ve aktiviteleri de hızla artmaktadır. Profesyonel hale gelen bu faaliyetlerin yönetimi için motive edici ve yönlendirici liderlere olan gereksinim de her geçen gün artmaktadır. Boş zaman aktivitelerinin bir lider tarafından yönlendirilmesi rekreasyon aktivitelerinin doğru ve sağlıklı yapılması yanında, toplumsal sermaye rolünün de yerine getirilmesine yardımcı olmaktadır. Bu aşamada gerçekleşecek liderlik başarısı ise içinde bulunulan duruma, rekreasyonistlerin profiline, aktivite 
uzmanlığına (Little ve Watkins 2004) ve liderin grup tarafından kabul görmesine bağlıdır (Jordan 1989). Liderin, grup üyeleri tarafından kabul görülebilmesi için liderin özelliklerinin ve davranışlarının, grup üyelerinin zihnindeki lider ile örtüşmesi gerekmektedir. Bu durum, örtük liderlik olarak ifade edilmektedir (Epitropaki ve Martin 2005: 660). Söz konusu durum, lider ve grubun olduğu her yerde gerçekleşmesi beklenen, psikolojik bir süreç olarak bilinmektedir. Rekreasyonel aktivitelerde örtük liderlik algısının ele alındığı örneklerin sayıca çok sınırlı olması bu çalışmanın konusunun, rekreasyonel liderlerle ilgili olarak yapılmasını gündeme getirmiştir. Bu durum, rekreasyonel liderlik çalışmalarının ivme kazandığı günümüzde, rekreasyonel liderlerin izleyicilerinin ya da rekreasyonistlerin zihninde nasıl bir imaja sahip olduklarının belirlenmesi ve sonuçlara göre rekreasyonel liderlik sürecinin oluşturulması bakımından önemlidir.

Örtük liderlik ile ilgili yapılan çalışmalar genellikle grup izleyicilerinin liderleri hakkındaki algılarına dayalı olarak gerçekleştirilmektedir (Koommoo 2008: 8-9). Bu bağlamda gerçekleştirilecek bu çalışmanın da örtük liderlik kuramına, özellikle rekreasyonel liderlik örneğinde önemli katkılar sağlaması beklenmektedir. Ayrıca, elde edilecek sonuçlar rekreasyonel liderlik, lider üye ilişki değerinin artırılması, grup ilişkilerinin grup beklentilerine göre yönetilmesi ve uygun liderlik rolünün sergilenmesi konularında sağlayacağı pratik sonuçları bakımından da önemlidir.

Araştırma, nicel araştırma yaklaşımıyla kurgulanmış, veriler anket aracılığıyla elde edilmiştir. Bu çalışmada, rekreasyon gruplarındaki katılımcrların (rekreasyonistlerin) lider beklentileri ve rolleri hakkındaki görüşlerinin belirlenmesi yanında, rekreasyon aktivitelerine katılanların örtük liderlikle ilgili önceliklerinin (faktörlerin) neler olduğu, aktivite türüne, eğitime, cinsiyete, yaşa ve gelire göre örtük liderlik algisında herhangi bir farklılaşma olup olmadığı yolunda bulgulara ulaşılması da amaçlanmaktadır.

\section{Rekreasyonel Liderlik Yaklaşımları}

Alanyazın incelendiğinde, rekreasyonel liderlikle ilgili ilk çalışmaların 1920'li yıllarda başladığı görülmektedir. Ulaşılabilen ilk çalışma ise toplumda ve kiliselerde rekreasyonel liderlik üzerinedir (Powell 1923). Bu çalışmada rekreasyonel liderin görevleri; bireylerin sağlıklarını ve kas kontrollerini iyileştirmek, arkadaşlık kurma ve iş birliği yapabilmelerine olanak tanıan sosyalleşme yönlerini güçlendirmek, yapmaktan zevk aldıkları ilgi alanlarını genişletmek, yeteneklerini geliştirmek, tanrıya olan sevgilerini artırmak ve yaşamdan zevk almalarını sağlamak olarak belirtilmiştir. 1950'li yıllara gelindiğinde, çalışmalar rekreasyonel liderin rollerine, aktivite planlamasına, ekipman hazırlığına ve aktivitenin yönetilmesi üzerine yoğunlaşmaya başlamıştır (Corbin 1953 ve Forsberg 1955'ten aktaran Long vd. 2001: 7). 1970'li yıllardan sonra yapilan rekreasyonel liderlikle ilgili çalışmalarda ise takipçi ile lider etkileşimi konuları ele alınmaya başlanmıştır (Danford ve Shirley 1970; Kraus ve Bates 1975). Bu amaçla lider ve takipçi arasındaki etkileşimin öğrenilmesi için bir model oluşturma (Phipps 1984: 171), lider ve takipçi arasındaki etkileşimin bazı demografik değişkenlere göre değerlendirilmesi (Ewert 1992) ve rekreasyonel liderlik ile grup dinamikleri (Irwin ve Phipps 1994; Kozak ve Yüncü 2008) gibi konulara ilginin arttığı görülmektedir. 1980'li yıllara gelindiğinde çalışmaların takipçileri göz ardı ederek yalnızca liderin sahip olması gereken özellikler üzerinden yapıldığı; liderin açık alanda hayatta kalabilme, medikal teknik bilgi (Green 1981), dürüstlük, ileriyi görme ve teşvik etme (Kouzes ve Posner 2006), teknik, güvenlik, çevresel, eğitsel ve karar alma yetenekleri (Priest ve Gass 2005: 3) gibi özelliklerinin yanında, birçok farklı özelliklere sahip olması gerektiği belirlenmiştir. 1980'li yıllardan sonra modern liderlik yaklaşımları benimsenmiş ve algıya dayalı liderlik anlayışı gündeme gelmiştir (Foti, Fraser ve Lord 1982). Ancak örgütlerde liderlik üzerine yapılan çalışmalarda sıkça ele alınan algıya dayalı liderlik anlayışının, henüz rekreasyonel liderlik bağlamında yeteri kadar ele alındığ 1 söylenemez.

Rekreasyonel liderliğin kimi zaman felsefi yaklaşımlarla ele alındığı da görülmektedir. Bu yaklaşımlardan ilki, Natüralizm'dir. Natüralizm, bireyi toplumdan daha önemli görür. Bireyin kendi eğitimine önem vermesinin ve katıldığı ak- 
tiviteyi öğrenmesinin önemini vurgulamaktadır (Lumpkin 1990). Natüralizm yaklaşımına göre rekreasyonistin katıldığı aktivitelerde yaptığı her bir davranışın doğal bir sonucu vardır. Bu doğal sonuçlar rekreasyonisti yaşama hazırlar (Cowell ve Welman 1963'ten aktaran Ağaoğlu ve Boyacı 2013: 4). Aktivite sirasinda rekreasyonistin karşılaşabileceği durumlar liderler tarafından anlatılmalıdır. Örneğin, katılımcının oyun oynarken sert oynarsa sakatlanabileceği veya bir dağa tırmanış esnasında kurallara uymadı tehlikeli durumlar içinde olabileceği gibi. Liderin bu rolü Little ve Watkins (2004: 83-88) tarafından yapılan çalışmada faaliyetlerin anlaşılması açısından liderlik rolü ile benzerlik göstermektedir. Faaliyetlerin anlaşılması bakımdan liderlik, takipçilerinin aktivite sonunda geniş bir alg1 ve öğrenmeye sahip olmalarını beklemektedir. Bu liderler aktivite içinde takipçilerinin her bir davranışının sonuçlarını açıklayarak katılımcı gruplar oluşturmayı isterler.

Rekreasyonel liderlikte diğer bir felsefi yaklaşım Realizm'dir. Realizm, doğa kanunlarını yorumlayarak gerçeğe ulaşma çabasıdır. Realist yaklaşıma göre rekreasyonun rolü gerçeği aramak, keşfetmektir. Bu da ancak lider ile gerçekleşebilmektedir. Öyle ki, realist lider öğrenmenin ve keşfetmenin devamlı olmasını sağlarken aktivite içinde rekreasyonistlere öğretilen bilgilerin yaşamın diğer alanlarında kullanılabilmesini sağlar (Lumpkin 1990). Liderlerin rekreasyonistlere öğrettikleri bilgilerin rekreasyonistler tarafından yaşamın diğer alanlarında kullanılabilmesi, liderin dönüştürücü liderlik tarzını benimsenmesiyle gerçekleşir. Tichy ve Devanna (1990) dönüştürücü liderin bulunduğu örgütte veya takipçilerinde bir değişim yaratması gerektiğini belirtmiştir. Dolayısıyla, rekreasyonistlerin öğrendikleri bilgileri yaşamın diğer alanında benimseyip kullanması, rekreasyonistler üzerinde bir değişim yaratması, liderin dönüştürücü rolü ile ilgilidir. Little ve Watkins (2004) çalışmalarında liderin bu rolünden, değişimi kolaylaştıran lider olarak bahsetmektedir. Değişimi kolaylaştıran liderlik tarzını benimseyen lider, rekreasyonistlerin bireysel değişimini teşvik eder ve onlar için rekreasyon faaliyetlerinin, rekreasyon davra- nışının ötesinde bir anlayışa dönüşmesini hedefler (Little ve Watkins 2004).

Pragmatist yaklaşımda rekreasyon, rekreasyonistlerin ve toplumun sosyal verimliliğini geliştirmeyi amaçlar. Liderin rekreasyonistlerin gereksinimlerine ve ilgilerine göre hareket etmesi, rekreasyonistlerin sosyal verimliliğini arttırır. Lider üye merkezli davranarak, rekreasyonistlerin daha fazla aktiviteye katılmasını sağlar. Grup ile yapılan aktiviteler bireylerarası becerilerin gelişmesine olanak tanır (Lumpkin 1990). Pragmatist yaklaşımın bu sosyal sorumluluk işlevi, rekreasyon teorisi içinde yer alan bireysel ve toplumsal olarak rekreasyon teorisi içinde ele alınabilir. Bu teoriye göre rekreasyon, bireylerin ve toplumların iyiliği için yüksek ahlak ve sosyal değerler standardına ulaşmada bir zorunluluktur (Torkildsen 2005: 53). Rekreasyon liderinin yönetim liderinden ayıran en önemli özelliği, rekreasyon liderinin toplumsal sermaye yaratma rolüdür (Pruijt 2002). Bu da ancak liderlerin, rekreasyonistlerin yeteneklerini geliştirmesini sağlaması ile mümkündür.

Lider ve rekreasyonistler arasındaki etkileşimde algılar yapısal bir harçtır. Bu yapısal harCı oluşturan faktör ise lider ve takipçi arasında gerçekleșen dinamik algılardır. Liderliğin, lider konumundaki bireyin o andaki durum içinde kendisine ve takipçilerin lidere ilişkin algılarının etkileșimi sonucu gerçekleşmektedir. Bir liderin gücü, bu algiya sahip kitlenin büyüklüğü ve alg1nın şiddetiyle doğru orantılıdır. Takipçilerin lider algısı; dini değerlerinden, kültürel değerlerinden ve kişisel tecrübelerinden etkilenerek oluşur. Bunun sonucunda takipçiler, potansiyel liderlerine liderlik vasfı yükler. Buna yükleme teorisi denir (Tabak, Şeşen ve Türköz 2012: 122- 257). Calder'a (1977) göre takipçilerin potansiyel liderlerine, lider yüklemesini yapabilmesi ise zihinlerindeki lider ile potansiyel liderin örtüşmesi ile gerçekleşir (Epitropaki ve Martin 2005: 660). Örtük liderlik olarak adlandırılan bu yaklaşım aslında, algıya dayalı tüm liderlik yaklaşımlarına dayanak oluşturan bir bakış açısıdır ve takipçilerin liderlerden beklentilerini, zihinlerinde var olan model ile karşılaştırmalarına olanak verir. Kişilerdeki bu hazır bilgilerle değerlendirme yapma ve var 
olan ile karşılaştırma ise incelenen konuyu örtülü olandan ortaya çıkarma gibi gerçeklik gösterir.

\section{Örtük Liderlik}

Rosch'un 1978 (Aktaran; Tabak, Şeşen ve Türköz 2012: 118) y1lında ortaya attığ kategorizasyon teorisini liderlik alanında uygulayan Lord, Foti ve De Vader (1984: 344) bireylerin zihninde yer alan kategorilere göre çevresindeki kişileri lider olan veya lider olmayan şeklinde tanımladıklarını belirtmişlerdir. Lord, Foti ve De Vader (1984) liderlik kategorizasyon modelini üç seviyeden oluşan bir yapı içinde açıklamaktadır. Hiyerarşik yapıda en üst seviye olarak nitelenen birinci basamak, algılayıcıların lider olan veya olmayan ayrımını yaptığı basamaktır. İkinci basamak ise temel düzey olarak adlandırılmıştır. Bu düzey, birinci düzeye göre daha az kapsayıcı olmasıyla beraber birçok farklı alandaki liderleri temsil ettiğinden (iş, askeri, politik gibi) bu alanlardaki liderlere yönelik en belirgin detayları kapsamaktadır. Üçüncü basamakta ise alt seviye kategoriler bulunmaktadır. Bu seviyede temel düzeydeki liderlik türlerinin daha özel türleri (politik lider, muhafazakâr lider gibi) yer almaktadır. Liderlik kategorizasyon teorisiyle takipçilerin zihinlerinde yer alan bilgiler bir başka teori olan yükleme (atıf) teorisiyle lidere atfedilir. Calder'in (1977) yükleme yaklaşımında liderliğin oluşabilmesi için potansiyel liderin, takipçilerin belirli beklentilerini karşılayacak davranışlar sergilemesi gerektiği vurgulanmıştır. Böylece, takipçi potansiyel liderini izleyecek ve kendi beklentileriyle uygun olduğu takdirde potansiyel lideri, lider olarak kabul edecektir (Lord ve Maher 2002: 50). Dolayısıyla, örtük liderliğin kategorizasyon ve yükleme teorilerinin sonrasında ortaya çıktığı söylenebilir.

Örtük liderlik üzerine yapılan araştırmalara bakıldığında çalışmaların, demografik değişkenler (Singer 1990; Van Emmerik vd. 2008), kültürel farklılıklar (Gerstner ve Day 1994; Dorfman vd. 1997) ve kişisel özellikler (Keller 1999) üzerine yapıldığ 1 görülmektedir. Cinsiyete göre örtük liderlik algısının farklılaşıp farklılaşmadığını ele alan çalışmalar incelendiğinde, kadınlara göre etkili liderliğin ortaya çıkabilmesi için liderin çalışma ortamında olumlu koşullar yaratması gerektiği düşüncesi ortaya çıkarılmıştır (Singer 1990). Benzer bir biçimde Paris'in 2004 yılında örtük liderlik algısı ile cinsiyet arasındaki ilişkiyi incelemek üzere 17 ülkeden veriler topladığ çalışmada, kadınların erkeklere oranla liderlerde katılımcılık özelliğine daha fazla önem verdiğ $i$ tespit edilmiştir. Amerika'da araştırma yapan Offerman, Kennedy ve Wirtz (1994) katılımcilardan liderlerin ve üstlerin özelliklerini sıralamalarını istemiş ve toplamda 160 özellik elde etmişlerdir. Araştırmacılar elde ettikleri 160 özelliği 41 özellik altında toplamışlardır. Sonuç olarak araştırmacılar, örtük liderlik üzerine bir ölçek geliştirmiş ve bu ölçekte hassasiyet, adanmışlık, karizma, zorbalık, çekicilik, zeka, güç ve erkeksilik olmak üzere sekiz faktör elde etmişlerdir. Farklı meslek gruplarında örtük liderlik modelinin genelleştirilebilmesi üzerine araştırma yapan Epitropaki ve Martin (2004) Offermann ve arkadaşlarının (1994) çalışmasını temel alarak daha kısa bir örtük liderlik teorileri skalası geliştirme yoluna gitmişlerdir. Nitekim araştırmacılar, yönetsel kademe, teknik kademe, büro işçisi ve satış departmanında çalışanlardan 21 tane örtük lider özellikleri elde etmişlerdir. Araştırmacılar Offerman, Kennedy ve Wirtz (1994) çalışmasından farklı olarak faktörleri, liderlik prototipi ve anti-prototip olarak ayırmışlardır.

Liderlik prototipi özelliklerini duyarlılık, zekâ, adanmışlık, dinamiklik; anti-prototip liderlik özelliklerini ise zorbalık ve erkeksi güç faktör yapıları olarak belirlemişlerdir. Amerika'da örtük liderlik üzerine yapılan çalışmalarda liderle ilgili özelliklerde güç, baskın olma, erkeksilik, zekâ, çekicilik gibi yönler ön plana çıkmaktadır (Offerman, Kennedy ve Wirtz 1994; Epitropaki ve Martin 2004). Çin'de fabrika işçileri, öğretmenler, üniversite öğrencileri ve teknisyenlerden oluşan 622 kişilik bir örneklem üzerinde örtük liderlik alg1larını ortaya koymaya çalışan Ling, Chia ve Fang (2000: 731, 733) kişisel ahlak, hedeflerde etkinlik, insanlararası yetenek ve beceriklilik olmak üzere dörtlü bir faktör yapısı elde etmiştir.

Kişisel özellikleri ve örtük liderlik arasındaki ilişkiyi belirlemek üzere yapılan bir araştırma beş faktör kişilik modeli üzerinden ele alınmıştır. Bu 
çalışmada takipçilerin aileden gelen özelliklerine sahip olan liderleri kabul edip içselleştirdikleri görülmüştür (Keller 1999: 597). Paşa (2000) ise Türkiye'de yöneticilerin ve çalışanların zihinlerindeki liderlik özelliklerini belirlemek üzerine bir araştırma yapmıştır. Bu kapsamda yöneticiler, liderin daha çok işe ve performansa yönelik özelliklerine yoğunlaşırken, çalışanlar liderin bilgili, adil olma, iyi ilişkiler kurma ve insancıl olma gibi görece daha duygusal özelliklere sahip olması gerektiğini belirtmişlerdir.

Kültürel farklılıklar üzerine Lübnan, Umman, Romanya ve İngiltere'de araştırma yapan Neal vd. (2007) bu ülkelerde yaşayan kadınların liderin otoritesine olan bakış açılarını ele almıştır. Bu çalışmada örtük liderlik faktörleri dört boyut oluşturmuştur. Araştırmacılar bu boyutlardan liderin, etkileyici, geleneksel ve bürokratik özelliklerini önceki çalışmalardan (Offerman, Kennedy ve Wirtz 1994; Paşa 2000; Epitropaki ve Martin 2004) farklı olarak ortaya çıkarmışlardır. Liderlik prototip özellikleri içinde yer alan karizma boyutu ise Offerman, Kennedy ve Wirtz (1994) çalışmasıyla ve Epitropaki ve Martin'in (2004) çalışmasıyla benzerlik göstermektedir. Söz konusu araştırma sonucunda, Umman ve Lübnanlı kadınların İngiliz kadınlara oranla bürokrasiyi daha fazla kabullendiği sonucuna ulaşılmıştır. Tabak, Kızıloğlu ve Polat'ın (2010) Ankara'da farklı sektörlerde çalışan toplam 117 kişilik örneklemde yaptıkları araştırmada, katılımcıların verdikleri yanıtlar, liderlik algılarına ilişkin olarak örtük lider özelliklerinin altı boyutunu ortaya koymuştur. Bu altı boyut temelde astların bir ideal liderden beklediği başlıca nitelikleri ifade etmektedir. Söz konusu boyutlar; dürüstlük ve güvenilirlik, beceriklilik, etkileyicilik/ilişkilerde beceri, dönüştürücülük, duyarlılık ve güçtür. Bu çalışmada dürüstlük ve güvenilirlik, dönüştürücülük ve beceriklilik boyutlarının önceki çalışmalardan farklı olarak ortaya çıkarılmış boyutlar olduğu görülmektedir. Türetgen ve Cesur (2010) tarafından yönetici liderliğe ve siyasi liderliğe yönelik olarak örtük liderlik teorilerinin karşılaştırıldığı çalışmada, yönetici liderler için kadınlar yenilikçi, erkekler ise disiplinli olma özelliğini; daha genç olan bireyler hoş görülü-anlayışlı, ileri görüşlü ve zeki olma, daha yaşlı olan bireyler demokratik olma özelliğini vurgulamışlardır. Örtük liderlik üzerine Türk toplum yapısına uygun hazırlanan bir ölçek olmadığını vurgulayarak Türk toplum yapısına uygun ölçek geliştirilmesi için çalışma yapan Tabak, Kızıloğlu ve Türköz (2013) kişisel ahlak, beceriklilik, duyarlılık, güç ve etkileyicilik olmak üzere beş faktörlü bir Örtük Liderlik Ölçeği geliştirmiştir. Söz konusu araştırmada, araştırmanın evreni Türkiye'de yaşayan 20 yaş üstü bireyler olarak ifade edilmiştir. Araştırmanın örneklemi ise Türkiye'nin farklı bölgelerinden değişik meslek ve eğitim seviyesine sahip 682 kişiden oluşmuştur. Ancak elde edilen bu ölçek rekreasyonel liderlik bağlamında uygulanmamıştır.

\section{YÖNTEM}

Nicel yaklaşımla hazırlanan bu çalışmada izlenen aşamalar; veri toplama aracının hazırlanmas1, pilot araştırmanın yapılması ve soru formuna son şeklinin verilmesi, çalışma evreninin seçilmesi ve verilerin analizi olarak planlanmıştır. $\mathrm{Bu}$ aşamalarla ilgili açıklamalara aşağıda alt başlıklar halinde yer verilmektedir.

\section{Soru Formunun Oluşturulması}

Soru formu, iki bölümden oluşmaktadır. Soru formunun birinci bölümünde, katılımcıların profilinin anlaşılmasını sağlayacak olan demografik sorular bulunmaktadır. Soru formunun ikinci bölümünde ise Tabak, Kızıloğlu ve Türköz (2013) tarafından "Örtülü Liderlik Ölçeği Geliştirme Çalışması" isimli araştırmasında yer alan örtük liderlik üzerine geliştirilmiş ölçek yer almaktadır. Söz konusu ölçeğin 27 maddelik örtük liderlik ölçeğinin içeriğini oluşturan beş faktörünün Cronbach's Alpha güvenilirlik değerleri ,66 ile ,91 arasında değişmektedir. Araştırmada ölçeğin toplam güvenilirlik değeri ise ,93 olarak ifade edilmiştir. Güvenirlilik değerlerinin beklendik düzeyde olması, ölçeğin bu çalışma için kullanılacağını gösterse de ölçeğin rekreasyon alanında ilk kez deneniyor olması bir pilot araştırmayı zorunlu hale getirmiştir. Ayrıca, Tabak, Kızıloğlu ve Türköz (2013) tarafından oluşturulan ölçekte ifadeler, 10'lu Likert tipi ile hazırlanmıştır. Bu çalışmada ise ifadelerin beş aralıklı olarak ölçülme- 
si hedeflenmiştir (1-kesinlikle katılmıyorum/5kesinlikle katılıyorum). Bu nedenle, ölçekte yer alan ifadelerin rekreasyon aktivitelerindeki kat1lımclar tarafından anlaşılma durumu ve beş aralığa indirgenmiş ölçeğin güvenirliğinin yeniden test edilmesi gerekmiştir. Bunun için Eskişehir'de açık ve kapalı alan rekreasyon aktivitelerine katılan bir örneklem grubu ( $\mathrm{n=182})$ üzerinde pilot uygulama gerçekleştirilmiştir. Pilot çalışma sonucunda, Tabak, Kızıloğlu ve Türköz (2013) tarafından 10'lu Likert tipinde hazırlanan soru formunda elde edilen güvenirlilik katsayısıyla, 5'li Likert tipinde hazırlanan soru formunun pilot çalışma sonucunda elde edilen katsayının birbirine yakın değerler olduğu görülmüştür. $\mathrm{Bu}$ kapsamda pilot araştırmanın güvenilirlik katsayısı (Cronbach Alpha) ,888 olarak hesaplanmıştır. Alpha değeri $0,60-0,80$ ve güvenilirlik değeri 0,80-1,00 aralığında ise güvenilirliğin yüksek olduğu belirtilmektedir (Kozak 2014: 146). Ayrıca, ölçekte yer alan soruların tamamının aktivite katılımciları (rekreasyonistler) tarafından anlaşıld1ğ1 görülerek, soru eliminasyonuna gidilmemiştir.

\section{Evren ve Örneklem}

Araştırmanın erişilebilir nüfusunu belirlenmesinde yargisal örneklem yöntemine başvurulmuştur. Yalnızca belirli bir aktiviteye yönelik oluşturulmuş sosyal medya grupları (dağcılık grubu, dalış kulübü vb.) yerine, tüm rekreasyon aktivitelerini kapsayan ve "rekreasyon" ve "boş zaman" ismiyle kurulan gruplar erişilebilir nüfus olarak belirlenmiştir. Rekreasyon ve boş zaman ismiyle kurulan sosyal medya gruplarının erişilebilir nüfus olarak belirlenmesinde, tüm rekreasyon aktivitelerini kapsamasına ve katılımcıların rekreasyon deneyimlerinin olmasına önem verilmiştir. Bu aşamadan sonra, "sosyal medya" üzerinden mesaj alma özelliği açı olan üyelere, araştırmacılar kendi sosyal medya hesaplarından özel mesajlar göndererek soru formunu 1500 grup üyesine ulaştırmışlardır. Bu noktada, katılımcilar, kolayda örneklem yöntemi ile belirlenmiştir. Veriler, 05.07.2016 ile 20.10.2016 tarihleri arasındaki üç aylık sürede toplanmıştır. Bu süre sonunda gelen 436 adet formdan 414 adedinin kullanılabilir olduğuna karar verilerek, araştırma bu sayı üzerinden yürütülmüştür. Evrenin bütününe ulaşılamayan durumlarda $\% 95$ güvenilirlik düzeyi için 384 örneklem sayısının yeterli olabileceği ifade edilmektedir (Sekaran 1992: 253; Saruhan ve Özdemirci 2011: 144). Bu nedenle, 414 anket sayısı yeterli bulunmuştur.

\section{Veri Analizi}

Verilerin analizine geçilmeden önce verilerin normal dağılıp dağılmadığına bakılmıştır. Bu amaçla öncelikle aritmetik ortalama, mod ve medyan değerlerine bakılmış ve bu değerlerin birbirine yakın olduğu görülmüştür. Ardından, verilerin basıklık ve çarpıklık değerleri incelenmiştir. Likert tipi ifadelerinin basıklık ve çarpıklık değerlerinin $\pm 1,5$ arasında yer aldığı görülmüş ve verilerin normal dağıldığı varsayılmıştır.

Analiz aşamasında öncelikle, örneklem grubunu tanımlayan ve rekreasyonistlerin, örtük liderlik algılarına ilişkin faktörlerin belirlenmesine çalışılmıştır. Bu kapsamda, frekans, yüzde, ortalama ve faktör analizinden yararlanılmıştır (Saruhan ve Özdemir 2011: 163; Büyüköztürk 2012: 281). Faktör analizi yapıldıktan sonra, faktör yapisıyla aktivite türü ve cinsiyet arasındaki farklılıklar T-Test ile analiz edilmiştir (Kalaycı 2014: 74). İki veya daha fazla grup arasındaki farklılıkların belirlenmesinde ise tek yönlü varyans analizinden (ANOVA) yararlanılmıştır. Faktör analizi kapsamında elde edilen faktör yapısıyla yaş, mezuniyet durumu ve gelir arasındaki farklılıklar tek yönlü varyans analizi (ANOVA) yardımıyla belirlenmiştir.

\section{BULGULAR}

Bu bölümde, araştırma kapsamında elde edilen sonuçlara yer verilmektedir. Bu amaçla, öncelikle, araştırma örneklemine ait tanımlayıcı demografik bilgilerin değerlendirilmesi yapılmıştır. 414 kişi kapsamında ulaşılan bilgilere Tablo 1'de yer verilmektedir. Tabloya göre katılımcıların büyük çoğunluğunu $(\% 95,9)$ 18-44 yaş aralığında olup yaş ortalaması 26,4' dür. 18-24 yaş kategorisi ise en fazla yoğunlaşan yaş aralığıdır. Bu yoğunlaşma, bu yaş grubunun sosyal medya kullanan ve ilgi duyduğu alanlara yönelik sayfaları takip eden kitle olmasına bağlanabilir. 
Katılımciların \%38,2'si kadın, \%61,8'i erkektir. Eğitim durumu bakımından, ilk ve orta öğretim mezunları $(\% 74,4)$ en büyük grubu oluştururken, bunu lisans ve yüksek lisans düzeyindeki eğitim izlemektedir. Araştırma kapsamında soru formunu yanitlayan katılımcılar, gelir durumu bakımindan değerlendirildiğinde, asgari ücret geçim düzeyi ve altında yer alan katılımcılarla birlikte yoksulluk sınırı içinde bulunan grubun, örneklemin \%92,5'lik bir kısmını temsil ettiği anlaşılmaktadır.

\section{Açıklayıcı Faktör Analizine Yönelik Bulgular}

Araştırma kapsamında faktör analizi uygulamadan önce verilerin faktör analizine uygunluğu test edilmiştir. Bu bağlamda, araştırmanın örnekleminin yeterliliğini ölçmek için Kaiser-MeyerOlkin (KMO) ve Bartlett Küresellik Testi'nden (Bartlett's Test of Sphericity) yararlanılmıştır. KMO değeri 0,815 olarak hesaplanmış ve araştırma örnekleminin yeterli olduğu (Subhash 1996: 116) belirlenmiştir. İkinci aşamada, Bartlett testinin sonuçları incelenerek testin anlamlı sonuç verdiği $(0,000<0,05)$ tespit edilmiştir. Ardından, örneklem yeterlilik değeri (MSA) kontrol edil-

Tablo 1. Demografik Değişkenler (Frekans Dağılımı)

\begin{tabular}{|c|c|c|}
\hline Yaş & $n$ & $\%$ \\
\hline $18-24$ & 211 & 51,0 \\
\hline $25-44$ & 186 & 44,9 \\
\hline 45 ve üstü & 17 & 4,1 \\
\hline Toplam & 414 & $\% 100$ \\
\hline \multicolumn{3}{|l|}{ Cinsiyet } \\
\hline Kadın & 158 & 38,2 \\
\hline Erkek & 256 & 61,8 \\
\hline Toplam & 414 & 100 \\
\hline \multicolumn{3}{|l|}{ Mezuniyet Durumu } \\
\hline Illk ve orta öğretim mezunu & 308 & 74,4 \\
\hline Lisans mezunu & 77 & 18,6 \\
\hline Lisansüstü mezunu & 29 & 7,0 \\
\hline Toplam & 414 & 100 \\
\hline \multicolumn{3}{|l|}{ Gelir } \\
\hline 1299 TL ve alt & 243 & 58,7 \\
\hline 1300-4518 TL & 140 & 33,8 \\
\hline 4519 TL ve üstü & 31 & 7,5 \\
\hline Toplam & 414 & 100 \\
\hline Aktivite Türü & $n$ & $\%$ \\
\hline Açık alan & 245 & 59,2 \\
\hline Kapalı alan & 169 & 40,8 \\
\hline Toplam & 414 & 100 \\
\hline
\end{tabular}

miştir. Bu kapsamda çapraz ilişki katsayıları incelenmiş ve 0,50'nin altında hiçbir değişkenin olmadığ (Durmuş, Yurtkoru ve Çinko 2013: 81) görülmüştür. Faktör sayısının belirlenmesinde özdeğere göre boyut belirleme yöntemi kullanılmış ve özdeğeri 1'den büyük olan faktörler, analize dâhil edilmiştir. Faktör analizi uygulanmasında dik döndürme yöntemlerinden biri olan "Varimax" yöntemi tercih edilmiştir. Faktörlerin belirlenmesinde faktör yükü değerinin en az 0,50 olmasına (Hair vd. 1998: 99) dikkat edilmiştir. Faktör analizi sonucunda dört faktör elde edilmiştir. Faktörlerin isimlendirilmesinde Tabak, Kızıloğlu ve Türköz'ün (2013) kullanımı dikkate alınmıştır.

Tablo 2'de görüldüğü üzere faktörlerin güvenilirlik katsayıları; 0,838 ile 0,880 arasında değişen değerlerde olup, ölçeğin toplam güvenilirlik katsayısı 0,868'dir. Bu sonuçlar ayrıca, birinci faktörün "beceriklilik" olduğunu ve varyansın $\% 17,79$ 'unu, ikinci faktörün "duyarlıl1k" ve varyansın \%15,61'ini, üçüncü faktörün "'kişisel ahlak" ve varyansın \%14,98'ini ve dördüncü faktörün ise "güç" faktörü olarak belirlendiğini ve varyansın \%13,69'unu açıkladığını göstermektedir. Faktör analizi sonucunda elde edilen bu bulgular, Tabak, Kızıloğlu ve Türköz'ün (2013) çalışmasından farklılık göstermektedir. Söz konusu çalışma, Türkiye'nin farklı bölgelerinde eğitim düzeyleri ve meslekleri birbirinden farklı 682 birey üzerinde gerçekleştirilmiştir. Araştırmacılar beş faktörlü bir yapı elde etmişlerdir. Çalışmada, kişisel ahlak faktörü toplam varyansın $\% 20$ 'sini, beceriklilik faktörü \%15,3'ünü, duyarlılık faktörü \%11,9'unu, güç faktörü $\% 7,52$ 'sini, etkileyicilik faktörü $\% 7,2$ 'sini açıklamaktadır. Ancak bu çalışmada "etkileyicilik" faktörü ayrı bir faktör olarak algılanmamıştır. Bu farklılık algıların, bir örgüt kapsamındaki çalışanı değil, rekreasyonel bir aktivite kapsamındaki katılımclardan toplanmasına ve "etkileyicilik" kapsamında yer alan ifadelerin güç faktörü kapsamındaki ifadelerle ilişkilendirilmesine bağlanabilir.

Faktör hiyerarşisinin en tepesinde beceriklilik faktörü yer almıştır. Bu faktör, liderlerin ileri görüşlü, işleri organize edebilen, problem çözebilen, ikna becerisi olan rekreasyonistleri eğiten ve motive edebilen, hızlı ve doğru karar verebilen 
Tablo 2. Örtük Liderlik Faktörleri (Faktör Analizi)

\begin{tabular}{|c|c|c|c|c|c|c|c|}
\hline \multirow[t]{2}{*}{ Faktör ve Ifadeler } & \multicolumn{4}{|c|}{ Faktör Yükleri } & \multirow[t]{2}{*}{ Ortalama } & \multirow[t]{2}{*}{ S.S. } & \multirow[t]{2}{*}{ Özdeğer } \\
\hline & 1 & 2 & 3 & 4 & & & \\
\hline \multicolumn{8}{|l|}{ Beceriklilik } \\
\hline 14- İleriyi gören & ,813 & & & & 3,59 & 1,08 & 6,300 \\
\hline 9- İşleri organize edebilen & ,811 & & & & 3,53 & 1,00 & \\
\hline 23- İkna kabiliyeti yüksek & ,739 & & & & 3,52 & 1,14 & \\
\hline 25- Eğitici & 709 & & & & 3,43 & ,99 & \\
\hline 10- Problem çözen &, 680 & & & & 3,57 & 1,08 & \\
\hline 12- Hızlı ve doğru karar veren & ,660 & & & & 3,54 & ,94 & \\
\hline 11- Motive edici &, 642 & & & & 3,43 & 1,01 & \\
\hline \multicolumn{8}{|l|}{ Duyarlılık } \\
\hline 4- İnsana değer veren & &, 857 & & & 2,90 & 1,05 & 4,024 \\
\hline 16- Tatlı-sert & &, 827 & & & 2,84 & 1,10 & \\
\hline 19- Cana yakın & & ,801 & & & 2,80 & 1,45 & \\
\hline 17- Cömert & & ,760 & & & 2,80 & 1,30 & \\
\hline 18- Hoşgörülü & & ,702 & & & 2,68 & 1,52 & \\
\hline 8- Katılımcıların güvenini kazanan & &, 535 & & & 3,28 & 1,11 & \\
\hline \multicolumn{8}{|l|}{ Kişisel Ahlak } \\
\hline 7- Şahsiyetli & & & ,823 & & 3,64 & 1,04 & 2,914 \\
\hline 1- Dürüst & & & ,802 & & 3,84 & 1,06 & \\
\hline 3- Hak yemeyen & & & ,795 & & 3,78 & 1,02 & \\
\hline 2- Adil & & & ,702 & & 3,79 & ,95 & \\
\hline 6- Özü sözü bir & & & ,694 & & 3,80 & 1,06 & \\
\hline 5- Saygı değer & & &, 571 & & 3,87 & ,96 & \\
\hline \multicolumn{8}{|l|}{ Güç } \\
\hline 24- Hitabeti kuvvetli & & & & 876 & 3,67 & ,94 & 2,284 \\
\hline 21-Tecrübeli & & & & ,812 & 3,75 & ,90 & \\
\hline 22- Otoriter & & & & 769 & 3,69 & ,99 & \\
\hline 15- Özgüveni olan & & & &, 620 & 3,69 & ,96 & \\
\hline 13- İnisiyatif sahibi & & & & ,596 & 3,61 & ,98 & \\
\hline \multirow[t]{2}{*}{ 20- Bilgili } & & & &, 551 & 3,68 & 1,04 & \\
\hline & 1 & 2 & 3 & 4 & Genel & & \\
\hline Açıklanan Varyans (\%) & 17,79 & 15,61 & 14,98 & 13,69 & 62,08 & & \\
\hline Cronbach's Alpha Güvenilirlik Katsayısı ( $\alpha$ ) & ,880 &, 866 & 857 & ,838 & ,868 & & \\
\hline
\end{tabular}

bir kişi olmasıyla ilgilidir. Bu faktör kapsamında Tabak, Kızıloğlu ve Türköz' ün (2013) çalışmasından farklı olarak liderin eğitici ve ikna kabiliyetinin olması etkileyicilik faktöründe değil, beceriklilik faktörü içinde görülmüştür. Bu farklılık, rekreasyon aktivitesine katılımın gönüllü olmasına bağlanabilir. Nitekim yapılan çalışmalarda, aktivite liderlerinin temel becerileri içinde eğitmek, motive etmek ve grup etkileşimini korumak yer almaktadır (Kraus 1985; Stokowski, Long ve Nuckolls 1992; Little ve Watkins 2004: 81). Benzer bir biçimde Mosley (1998) liderlerin ikna etme ve problemleri çözme kabiliyetini kişisel beceriklilik olarak ifade etmiştir. Özellikle, açık alan aktivitelerinde beklenmedik bir durum karşısında (fırtına çıkması, çı̆̆ düşmesi, böcek sokması, sakatlanma) liderin ileriyi görmesi, hıl1 ve doğru karar verebilmesi, işleri organize edebilmesi gibi becerilere sahip olması gerekmektedir. Paşa (2000) tarafından yapılan çalışmada da çalışanların liderlerinden beceriklilik bekledikleri ortaya çıkmıştır. Ancak Offerman, Kennedy ve Wirtz (1994) ile Epitropaki ve Martin'in (2004) çalışmalarında beceriklilik faktörü yer almamıştır.

İkinci öneme sahip faktör, duyarlılıktır. Bu faktör içinde yer alan tatlı-sert, cömert, insana değer veren, hoşgörülü, cana yakın ve rekreasyonistlerin güvenini kazanan ifadeleri liderin rekreasyonistlere karşı duyarlı bir yapıda olduğunu göstermektedir. Liderin örgütsel başarısı ve performansı üzerine araştırma yapan Rush, Thomas 
ve Lord (1977), katılımcıların başarılı buldukları lider tipinin hem duyarlılık hem de katılımciyı harekete geçirme özelliğinin yüksek olması gerektiğini ortaya koymuşlardır. Çin'de örtük liderlik üzerine yapılan bir araştırmada duyarlılık faktörü içinde yer alan ifadelerin, "insanlar arası yeterlilik" adı altındaki başka bir faktörü altında yer aldığı görülmektedir (Ling, Chia ve Fang 2000: 734). Offerman, Kennedy ve Wirtz (1994) tarafından yapılan çalışmada ise hassasiyet faktörü altında yer alan bu ifadeler, bu çalışmada duyarlılık faktöründe toplanmıştır.

Kişisel ahlak faktörü liderlerinin, hak yemeyen, dürüst, adil, göründüğü gibi olan, saygı değer kişilik yapısına sahip olmasıyla ilgili beklentileri göstermektedir. Liderin kişisel ahlâka sahip olması, katılımcıların lideri takip etmesi için lider modeli oluşturmasında bir gerekliliktir (Palmer 2009: 528). Liderde bulunması gereken ahlak anlayışına Treviño, Hartman ve Brown (2000) bütüncül bir bakış açısı getirerek ahlakı, ikili sütun yaklaşımıyla ele almışlardır. Bu kapsamda Karaküçük (2005: 288-291) rekreasyonel liderde bulunması gereken özellikleri dürüst olma, sözlerinde tutarlı davranma, adil ve objektif karar verebilme olarak belirtmiştir. Ancak Offerman, Kennedy ve Wirtz'in (1994) çalışmasında ve Epit- ropaki ve Martin'in (2004) çalışmasında örtük lider özellikleri arasında kişisel ahlak faktörü yer almamıştır. Ayrıca, kişisel ahlak faktörü Tabak, Kızıloğlu ve Polat'ın (2010) çalışmasında dürüstlük ve güvenilirlik faktörü altında yer alırken, Türetgen ve Cesur'un (2010: 59) çalışmasında, liderin ve yöneticinin ahlaklı ve dürüst olma özellikleri önemli değişkenler olarak belirlenmiştir.

Rekreasyonel liderlere atfedilen bir diğer faktör, güçtür. Bu faktör liderin bilgili, hitabeti kuvvetli, tecrübeli ve otoriter olması, inisiyatif sahibi, öz güven sahibi olması gibi özelliklere işaret etmektedir. Güç faktörü altında yer alan bilgili ve tecrübeli olma alanyazındaki uzmanlık gücü ve karizmatik güç ile açılanabilir. Uzmanlık gücü liderin işinde sahip olduğu bilgi, beceri birikimi; karizma ise katılımcılar tarafından lidere duyulan hayranlık ve hayranlığa bağlı kabul edilmedir (Maviş 2006: 176; Kozak vd. 2013: 178; Koçel 2014: 654).

\section{Farklılıklara ilişkin Bulgular}

Araştırmada, açık ve kapalı alan aktiviteleri, yaş, eğitim, cinsiyet ve gelirle örtük liderlik algısı arasındaki kimi farklılıklar olduğu da belirlenmiştir. Farklılıklarla ilgili Tablo 3 ve Tablo 4'e aşağıda yer verilmektedir.

Tablo 3. Cinsiyet ve Aktivite Türüne Göre Örtük Liderlik Algılaması (T Testi)

\begin{tabular}{|c|c|c|c|c|c|c|}
\hline Faktörler & Katılımcılar & Siklık & $x$ & S.S. & T Değeri & P Değeri \\
\hline \multirow[t]{2}{*}{ Beceriklilik } & Açık Alan & 245 & 3,89 & 1,03 & $-2,930$ &, $001^{*}$ \\
\hline & Kapalı Alan & 169 & 3.32 & ,79 & & \\
\hline \multirow[t]{2}{*}{ Duyarlılık } & Açık Alan & 245 & 3,04 & ,98 & $-4,065$ &, $000^{*}$ \\
\hline & Kapalı Alan & 169 & 2,65 & ,94 & & \\
\hline \multirow[t]{2}{*}{ Kişisel Ahlak } & Açık Alan & 245 & 3,69 & ,78 & 2,976 & $003^{*}$ \\
\hline & Kapalı Alan & 169 & 3,92 & ,75 & & \\
\hline \multirow[t]{2}{*}{ Güç } & Açık Alan & 245 & 3,73 & ,76 & $-1,697$ & 101 \\
\hline & Kapalı Alan & 169 & 3,61 & ,64 & & \\
\hline \multirow[t]{2}{*}{ Beceriklilik } & Kadın & 158 & 3,64 & 89 & 2,683 &, $008^{*}$ \\
\hline & Erkek & 256 & 3,43 & ,71 & & \\
\hline \multirow[t]{2}{*}{ Duyarlılık } & Kadın & 158 & 2,78 & 1,05 & $-1,522$ & ,129** \\
\hline & Erkek & 256 & 2,94 & ,93 & & \\
\hline \multirow[t]{2}{*}{ Kişisel Ahlak } & Kadın & 158 & 3,67 & ,79 & $-2,393$ &, $017^{*}$ \\
\hline & Erkek & 256 & 3,86 & ,76 & & \\
\hline \multirow[t]{2}{*}{ Güç } & Kadın & 158 & 3,78 & 80 & 2,182 &, $030 * / * *$ \\
\hline & Erkek & 256 & 3,62 & ,65 & & \\
\hline
\end{tabular}

*Katılımcıların örtük liderlik algısında bir farklılık mevcuttur.

**Varyanslar homojenlik göstermemektedir. 
Açık ve kapalı alan aktivitelerine göre örtük liderlik algısına yönelik güç faktöründe anlamlı bir farklılık bulunamamıştır. Ancak beceriklilik, duyarlılık ve kişisel ahlak faktörüne bakıldığında açık ve kapalı alanda örtük liderlik algısının farklılaştığı görülmektedir. Faktör ortalamaları açık alan aktivitelerine katılanların liderinde beceriklilik, duyarlılık ve kişisel ahlak konularına daha fazla önem verdiklerine işaret etmektedir. Tablo 3 'te cinsiyete göre örtük liderlik algısına yönelik sonuçlar da yer almaktadır. Bakıldığında, sadece duyarlılık faktöründe farklılık bulunamamış- tır. Beceriklilik ve güç faktörlerinde kadınlar ile erkekler arasında, kadınların bu faktörleri daha fazla önemsemesinden kaynaklanan farklılık vardır. Kişisel ahlak faktöründe ise erkek katılımcılar, kadınlardan daha fazla tercih sıklığında bulunmuşlardır.

Katılımcıların yaş, gelir ve eğitim durumuna göre örtük liderlik algılarının farlılıklarını belirlemek için tek yönlü varyans analizinden yararlanılmıştır. Bu kapsamda yaş grupları 18-24, 2544 ve 45 ve üzeri olarak üç gruptan; gelir grupları 1299 ve altı (asgari ücret alt1), 1300-4518 (asgari

Tablo 4. Eğitim Düzeyine Göre Örtük Liderlik Faktörleri (ANOVA)

\begin{tabular}{|c|c|c|c|c|c|c|c|}
\hline \multirow{5}{*}{ Beceriklilik* } & Varyansın & Kareler & \multirow{2}{*}{$s d$} & Kareler & \multirow{2}{*}{$F$} & \multirow{2}{*}{$p$} & \multirow{2}{*}{$\begin{array}{c}\text { Anlaml } \\
\text { Fark }\end{array}$} \\
\hline & Kaynağı & Toplamı & & Ortalaması & & & \\
\hline & Gruplar arası & 12,798 & 2 & 6,399 & 10,627 &, 000 & \multirow{3}{*}{$\begin{array}{l}2-1 \\
3-1\end{array}$} \\
\hline & Gruplar içi & 247,481 & 411 & ,602 & & & \\
\hline & Toplam & 260,280 & 413 & & & & \\
\hline \multirow{5}{*}{ Duyarlılık } & Varyansın & Kareler & & Kareler & $\Gamma$ & & Anlamlı \\
\hline & Kaynağı & Toplamı & & Ortalaması & & $\mu$ & Fark \\
\hline & Gruplar arası & 11,209 & 2 & 5,605 & 10,627 & ,003 & \multirow{3}{*}{$3-1$} \\
\hline & Gruplar içi & 389,348 & 411 & 947 & 5,916 & & \\
\hline & Toplam & 400,557 & 413 & & & & \\
\hline \multirow{5}{*}{ Kişisel Ahlak } & Varyansın & Kareler & \multirow{2}{*}{$s d$} & Kareler & \multirow{2}{*}{$F$} & \multirow{2}{*}{$p$} & Anlamlı \\
\hline & Kaynağı & Toplamı & & Ortalaması & & & Fark \\
\hline & Gruplar arası & 999 & 2 &, 500 & 821 & ,441 & \multirow{3}{*}{---} \\
\hline & Gruplar içi & 250,022 & 411 & ,608 & & & \\
\hline & Toplam & 251,021 & 413 & & & & \\
\hline \multirow{5}{*}{ Güç } & Varyansın & Kareler & \multirow{2}{*}{$s d$} & Kareler & \multirow{2}{*}{$F$} & \multirow{2}{*}{$p$} & Anlamlı \\
\hline & Kaynağı & Toplamı & & Ortalaması & & & Fark \\
\hline & Gruplar arası & 18,717 & 2 & 9,359 & 19,752 & ,000 & \multirow{3}{*}{$\begin{array}{l}2-1 \\
3-1\end{array}$} \\
\hline & Gruplar içi & 194,739 & 411 & 474 & & & \\
\hline & Toplam & 213,456 & 413 & & & & \\
\hline
\end{tabular}

*Varyans homojenlik göstermemektedir.

(1: ilk ve orta öğretim mezunu, 2: lisans mezunu, 3: lisansüstü eğitim mezunu) 
Meryem Akoğlan Kozak - Çağdaş Aydın - Ceren Aydın

Tablo 5. Eğitim Düzeyi İle Örtük Liderlik Faktörleri İlişkisi

\begin{tabular}{|c|c|c|c|c|c|c|}
\hline Faktörler & Mezuniyet Durumu & Sıklık & Ortalama & F Değeri & P Değeri & Fark \\
\hline \multirow{3}{*}{ Beceriklilik } & İlk ve Orta Öğretim M. & 308 & 3,42 & \multirow{3}{*}{10,627} & \multirow{3}{*}{, 000} & \multirow{3}{*}{$\begin{array}{l}3 / 1^{*} \\
2 / 1^{*}\end{array}$} \\
\hline & Lisans M. & 77 & 3,72 & & & \\
\hline & Lisansüstü M. & 29 & 3,99 & & & \\
\hline Toplam & & 414 & 3,51 & & & \\
\hline \multirow{3}{*}{ Duyarlıık } & İlk ve Orta Öğretim M. & 308 & 2,82 & \multirow{3}{*}{5,916} & \multirow{3}{*}{, 003} & \multirow{3}{*}{$3 / 1$} \\
\hline & Lisans $\mathrm{M}$. & 77 & 2,89 & & & \\
\hline & Lisansüstü M. & 29 & 3,47 & & & \\
\hline Toplam & & 414 & 2,88 & & & \\
\hline \multirow{3}{*}{ Kişisel Ahlak } & İlk ve Orta Öğretim M. & 308 & 3,76 & \multirow{3}{*}{,821 } & \multirow{3}{*}{,441 } & \multirow{3}{*}{---} \\
\hline & Lisans M. & 77 & 3,88 & & & \\
\hline & Lisansüstü M. & 29 & 3,83 & & & \\
\hline Toplam & & 414 & 3,78 & & & \\
\hline \multirow{3}{*}{ Güç } & İlk ve Orta Öğretim M. & 308 & 3,56 & \multirow{3}{*}{19,752} & \multirow{3}{*}{, 000} & \multirow{3}{*}{$\begin{array}{l}3 / 1 \\
2 / 1\end{array}$} \\
\hline & Lisans M. & 77 & 4,02 & & & \\
\hline & Lisansüstü M. & 29 & 4,10 & & & \\
\hline Toplam & & 414 & 3,68 & & & \\
\hline
\end{tabular}

*Varyans homojenlik göstermemektedir

ücret ve yoksulluk sınırı) ve 4519 ve üzeri olarak üç gruptan; eğitim düzeyi ise ilk ve orta öğretim mezunu, lisans mezunu ve lisansüstü eğitim mezunu olmak üzere üç gruptan oluşmaktadır. Yaş, gelir ve eğitim gruplarına göre örtük liderlik algısına bakıldığında, yaş ve gelir grupları arasında örtük liderlik algısının farklılaşmadığı, ancak, eğitim düzeylerine göre algıların farklılaştığ ${ }_{1}$ belirlenmiştir. Bu bağlamda elde edilen sonuçlara Tablo 4 'te yer verilmektedir.

Tablo 4'te verilen varyans analizi (ANOVA) sonuçları, katılımcıların eğitim düzeyleri ile örtük liderlik algılarından beceriklilik, duyarlılık ve güç faktörlerinde anlamlı bir farklılık göstermektedir $(\mathrm{p}<0,05)$. Bu sonuçların ardından ortaya çıkan anlamlı farklılığın hangi gruplardan kaynaklandığını belirlemek üzere post-hoc analizleri ve Levene's testleri uygulanmıştır. Sonuçta, bece- riklilik faktöründe varyansların homojen olmadığ1 saptanmıştır. Bunun üzerine, diğer çoklu karşılaştırma testlerine kıyasla daha güçlü sonuçlar veren Games-Howell testi tercih edilmiştir (Morgan vd. 2012: 194). Varyansların homojen dağılma varsayımını sağlayan diğer iki faktör içinde hangi grupların farklılaştığını anlamak için Scheffe testinden yararlanılmıştır (Myers, Well ve Lorch 2010: 260). Beceriklilik ve güç faktörlerinde lisansüstü mezunlarının faktör ortalamaları hem lisans mezunlarından hem de ilk ve orta öğretim mezunlarından yüksek çıkmıştır. Bu noktada, belli bir eğitim düzeyine sahip olan katılımcıların, rekreasyon aktivitesi esnasında kendilerine yol gösterecek liderlerinin, belli bir güce ve beceriye sahip olmasını bekledikleri söylenebilir. Ayrıca, güç ve beceriklilik faktörlerinde, lisans mezunlarının faktör ortalaması ilk ve orta öğretim mezunlarının ortalamasından yüksek çıkmıştır. 
Kısaca, eğitim düzeyindeki artış, beceriklilik ve güç algısında anlamlı bir fark oluşturmaktadır. Bir diğer ifadeyle, eğitim düzeyi arttıkça, rekreasyonel liderlerin güçlü olma ve temel becerilere sahip olma beklentisi de artmaktadır. Duyarlılık faktöründe ise lisansüstü mezunlarının faktör ortalaması, diğer eğitim seviyesindeki katılımcıların ortalamasından yüksek çıkmıştır. Bu çerçeveden bakıldığında, belli bir uzmanlık alanına sahip olan katılımcilar aktivite esnasında kendilerini yönlendirecek liderlerin tatl1-sert, cömert, insana değer veren, hoşgörülü cana yakın ve katılımcıların güvenini kazanan özelliklere sahip olmasını beklemektedir. Kişisel ahlak faktörü incelendiğinde, katılımcıların faktör ortalamalarının birbirine yakın olduğu, dolayısıyla eğitim düzeyine göre bu faktörün farklılaşmadığı sonucuna ulaşılmaktadır. Ancak liderin sahip olduğu güç, beceriklilik ve duyarlılık özellikleri katılımcıların eğitim düzeyine göre farklılaşırken, liderin ahlaklı olması katılımcıların eğitim düzeyine bağlı olmaksızın liderde olması gereken doğal bir özellik olarak kabul görmektedir.

Tablo 5 incelendiğinde eğitim düzeylerine göre farklılaşan faktörlerin beceriklilik, duyarlılık ve güç olduğu görülmektedir. Örtük liderlik algısındaki beceriklilik faktörüne eğitim düzeyi arttıkça katılımcılar tarafından daha fazla önem verildiği görülmektedir. Benzer bir biçimde, eğitim düzeyi arttıkça liderde aranan güç faktörü katılımcılar tarafından daha fazla önemli hale gelmektedir. Duyarlılık faktörüne bakıldığında ise farklılaşma lisansüstü mezunlar ile ilk ve orta öğretim mezunları arasındaki geniş uçurumlu alanda ortaya çıkmaktadır.

\section{SONUÇ VE ÖNERILER}

Rekreasyon aktivitelerinden daha fazla doyum elde etmek, kaynakların ve zamanın etkili bir biçimde kullanılması için rekreasyonel liderlere gereksinim duyulmaktadır. Rekreasyonel lider, rekreasyonistlerin yer aldığ 1 rekreatif aktivitedeki amaçlara ulaşmasına yardım eden veya beklenen rekreatif çıtıları elde etmek için onları motive eden kişiler olarak tanımlanmaktadır (Edginton, Hudson ve Ford 1999: 77). Bu bağlamda rekreasyon liderlerini, herhangi bir örgüt içinde- ki liderlerden ayıran en temel fark, takipçileri ve bağlamıdır denilebilir. Rekreasyonistler olarak adlandırılan takipçiler, gönüllü olarak aktivitelere katılır ve para kazanma amacı gütmezler. Rekreasyonistlerin aktivitelere bağlanmasında yasal ya da örgütsel bir zorunluluk olmadığından liderin, motivasyon ve grup dinamiklerine göre hareket etmesi çok önemlidir. Bu bakış açıs1, rekreasyonel faaliyetlerin natüralizm, realizm ve pragmatizm gibi kimi felsefi yaklaşımlarla da açıklanmasına dayanak oluşturabilir, liderlik ile ilgili tercihlerin daha iyi anlaşılmasını sağlayabilir. Ancak liderlik ile ilgili çalışmaların ağırlıklı olarak, örgütsel yapı içinde gerçekleşmesi ve liderliğin farklı paradigmalara göre kategorize edilerek açıklanması bu felsefi bakış açsının gözardı edilmesine neden olmuştur. Belirlenen otoriter, insana dönük, görev odaklı, stratejik, girişimci, babacan, serbestçi, etkili, misyoner, karizmatik, dönüşümcü ve hizmetkâr lider kategorileri bunlardan bazılarıdır. Bu gruplandırmalarda kimi zaman liderin özellikleri, kimi zaman davranışları etkili olurken, son yıllarda kabul gören durumsal bakış açısında ise takipçiler ve ortamın etkili olduğu bilinmektedir. Dolayısıyla, liderle ilgili açıklamalarda takipçilerin önemsenmesinin durumsallık yaklaşımıyla önem kazanmaya başladığı söylenebilir. Bu bakış açısı sonrasında, güdülenmiş lider, katılımcı lider, lider üye etkileşimi, algıya dayalı liderlik ve örtük liderlik gibi tamamen takipçilerin zihinlerinde oluşturdukları ve onların kalıp yargılarına göre şekillenen liderlik modelleri ortaya çıkmıştır. Eğer, lider bu tanımlanmış kategoriler kapsamında değil, takipçilerin beklentilerine göre anlaşılmak isteniyorsa veya alanda bu kapsamda, örneğin, rekreasyonel liderlikte olduğu gibi doğrudan farklı bir bağlama uygulanacak model sıkıntısı varsa, o noktada takipçilerin beklentileri hatta örtülü düşüncelerinin ve algılarının belirlenmesi yol gösterici olacaktır. Bu araştırmada da aslında yapılan budur. Çalışmada, rekreasyonistlerin zihnindeki ideal rekreatif lider tipinin özelliklerinin belirlenmesi yanında, bu özelliklerin faktöriyel dağılımlarına ve dayanaklarına da bakılmıştır.

$\mathrm{Bu}$ araştırma kapsamında yapılan analizler sonucunda, rekreasyonel liderlikte etkili olan dört 
önemli faktör belirlenmiştir. Bunlar beceriklilik, duyarlılık, kişisel ahlak ve güçtür. Güç ve duyarlılık faktörleri (Offerman, Kennedy ve Wirtz 1994; Epitropaki ve Martin 2004) daha önceki çalışmalarda en önemli olarak algılanırken, bu çalışmada daha az önemli düzeyde bulunmuştur. Eroğluer (2014), Tabak, Kızıloğlu ve Türköz (2013) ile Neal ve arkadaşlarının (2007) yaptığ 1 çalışmalarda ortaya çıkan etkileyicilik faktörü ise bu araştırmada bir faktör olarak belirlenmemiş, faktörle ilgili ifadeler, beceriklilik ve güç faktörü altında dağılmıştır.

Araştırmada en yüksek faktör olarak belirlenen becerikliliğin, daha önceki bir araştırmada (Ling, Chia ve Fang 2000) en düşük seviyede algılanmaS1, aslında rekreatif faaliyetlerdeki lider algısının nasıl değiştiğini göstermesi bakımından önemlidir. Bu farklılaşmada liderlik edilen ortamın iş değil dinlence olması yanında, izleyicilerin çalışan değil gönüllü olmalarının ve serbestlik içinde bu aktivitelerde bulunmalarının da belirleyici olduğu görülmektedir. Beceriklilik faktörü; bir rekreasyonel liderin aktivite sırasındaki riskleri önceden görebilmesi ve rekreasyonistleri uyarması, ileriyi görmesi, hızlı ve doğru karar verebilmesi, problem çözebilmesi gibi yetkinliklerini temsil etmekte ve bu liderler için hayati önem taşımaktadır. Beceriklilik faktörünün rekreasyonel liderlik bağlamındaki bu önemi aynı zamanda, natüralizm bağlamındaki önermelerde de karşılık bulmaktadır. Bilindiği gibi natüralizmde rekreasyonistin katıldığı aktivitelerde yaptığ her bir davranışın doğal bir sonucu vardır ve bu doğal sonuçlar rekreasyonisti yaşama hazırlar (Cowell ve Welman 1963'ten aktaran Ağaoğlu ve Boyacı 2013: 4). Bu nedenle, aktivite sirasinda rekreasyonistin karşılaşabileceği durumlar liderler tarafından bilinmeli ve rekreasyonistlere anlatılmalıdır. Ayrıca, beceriklilik faktörünün, rekreasyonel liderlerin sosyal verimliliğin arttırılması ve bireylerarası becerilerin gelişmesiyle de ilgili olduğu düşünüldüğünde, bu faktöre atfedilen önem durumu pragmatist bakış açısıyla da açıklanabilir.

Bu araştırmada, duyarlılık faktörü ikinci sırada önemli görülmektedir. Oysa bu faktör önceki çalışmalarda (Tabak, Kızıloğlu ve Türköz 2013) takipçiler tarafından daha az önemle algılanmıştır.
Buradaki farklılık, rekreasyon aktivitelerine katılımın gönüllü olması ve her rekreasyonistin kendisine özel ilgi beklemesiyle açıklanabilir. Başka bir deyişle, rekreasyonistler liderlerinden kendilerine değer veren, cana yakın davranan, hoşgörülü ve güvenli davranışlar beklemektedirler. $\mathrm{Bu}$ sonuç aynı zamanda, natüralizm bağlamındaki açıklamalara da işaret etmektedir. Bilindiği gibi natüralizm, bireyi toplumdan daha önemli görür (Lumpkin 1990) ve bireysel tatminin üst düzeyde sağlanmasını önemser.

Üçüncü önem düzeyle algılanan kişisel ahlak faktörü (Ling, Chia ve Fang 2000; Tabak, Kızıloğlu ve Türköz 2013) diğer çalışmalarda, takipçiler tarafından en önemli olarak algılanmıştır. Burada ortaya çıkan sonuç, rekreasyonel liderlikteki ortam koşullarına bağlanabilir. Çünkü örgütsel çalışma ortamında terfi etme, prim alma, yetki ve sorumluluk alanlarının genişlemesi gibi uygulamalarda liderlerin adaletli, hak yemeyen, dürüst ve özü sözü bir olması beklenmektedir. Rekreasyonel aktivitelerde böyle bir iş ortamı ilişkisi olmadığından, katılımcılar bu faktörü daha az önemli olarak algılamışlardır. Ancak bu faktörün, rekreasyonel liderlikte de üçüncü sırada önemli olarak algılanması, kişisel ahlakın vazgeçilmez olduğuna ve grup dinamiği, grup ile üye ilişkisi açısından önemli olduğuna işaret etmesi bakımından dikkate değerdir. Bu faktörle ilgili ortaya çıkan diğer bir sonuç ise liderlerin rekreasyonistleri ahlaki açıdan geliştirmeye çalıştığı, rekreasyonistlerin de liderlerinden ahlaklı olmayı beklediklerini göstermektedir. Ahlaklı olmak konusuna pragmatist açıdan bakıldığında, toplumların yüksek ahlak ve sosyal değer standartlarına ulaşmasının amaçlandığ 1 (Torkildsen 2005: 53) görülür. Bu yaklaşımın barındırdığı, ahlak ve sosyal sorumluluk işlevi, kişisel ahlak faktörünün bu bağlamdaki önemine işaret etmektedir.

Güç faktörü bu çalışmada dördüncü sırada önemli bir faktör olarak belirlenmiştir. Bu sonuç, önceki çalışmalarla (Offerman, Kennedy ve Wirtz 1994; Tabak, Kızıloğlu ve Polat 2010; Tabak, Kızıloğlu ve Türköz 2013) benzerdir ve rekreasyonel lidere yönelik güç algısıyla, bir örgüt liderine yönelik güç algısının farklı olmadığını göstermektedir. Bu durum her iki grupta yer 
alan takipçilerin liderin gücünü uzmanlık ve karizmatik unsurlara bağlamalarına bağlanabilir. Başka bir deyişle, ister bir kurumda ya da örgüt yapısı içinde, ister bir aktivite grubunda ve gönüllük esasına göre ortaya çıksın, liderin yönettiği işi bilmesi ve karizmatik olması önemlidir. Liderin bilgili olması ve karizmatik olarak alg1lanması aynı zamanda, değişimi kolaylaştırıcı ve davranışları dönüştürücü bir etki yaratacaktır. Bilgi ve güce dayalı bu bakış açısı, rekreasyonist algılarının realizm temelinde de açıklanabilir olduğuna gönderme yapmaktadır.

Buraya kadar yapılan açılamalara bağlı olarak, rekreasyonel liderin, örgüt temelli liderlik modellerinden farklı olduğu, ancak bu farklılığın ortaya çıkmasında ortamın ya da bağlamın belirleyici olduğu ileri sürülebilir. Dolayısıyla, örtük liderlik modeliyle açıklanmaya çalışılan rekreasyonel liderliğin, aynı zamanda, durumsallık kuramı ve kimi felsefi yaklaşımlarla da açıklanabileceği söylenebilir.

Araştırmada, rekreasyonel liderlikle ilgili örtük algıların bazı göstergeler itibariyle farklılaştığı da görülmüştür. Örneğin, kapalı alanda yapılan aktivitelerde duyarlılık ve kişisel ahlak faktörleri açık alanda yapılan aktivitelerden daha fazla önemsenmektedir. Çünkü açık aktivite alanlarına kıyasla daha küçük ve kapalı olan bu samimi alanlardaki rekreasyonistler, liderlerinden cana yakın, hoşgörülü ve insana değer veren özelliklere sahip olmasını beklemektedirler. Cinsiyet bağlamında farklılık olduğunu ileri süren (Singer 1990; Paris 2004) araştırmaları destekleyen sonuçlara göre, kadın rekreasyonistler liderde beceriklilik ve gücü önemserken; erkek rekreasyonistler kişisel ahlak faktörüne önem vermektedirler. Bir diğer ifadeyle, kadın rekreasyonistler, liderlerin -aktiviteyi başarılı bir biçimde yürütüp sonlandırabileceği- doğrudan liderin aktiviteyle ilgili özelliklerine odaklanmışlardır. Eğitim durumu itibariyle örtük liderlik algılarında da farklılık saptanmıştır. Eğitim seviyesinin artmasının beceriklilik, duyarlılık ve güç faktörlerinde farklılık yarattığı görülmüştür. Söz konusu üç faktörde de lisans ve lisansüstü eğitim almış kişilerin ilk ve orta öğretim mezunlarının ortalamasına oranla her iki özelliğe daha fazla önem verdiği ortaya çıkmıştır. Kişisel ahlak faktörünün ise eğitim düzeyine göre farklılaşmaması ise çarpıcı sonuçlardan biridir. Bu durum, hangi eğitim seviyesindeki gruplarla çalışılırsa çalışılsın rekreasyonel liderin kişisel ahlaka sahip olması gerektiğine işaret etmektedir. Ayrıca, eğitim düzeyi attıkça liderden beklenen beceriklilik beklentisinin de arttığ1 gözlenmiştir.

Sonuçta, açık alan rekreasyonel liderlerinde ileriyi gören, işleri organize edebilen, problem çözen, hızlı ve doğru karar veren, takipçilerini motive eden ve eğiten özelliklere sahip olması beklenmektedir. Kapalı alan liderlerin ise cana yakın, cömert, hoşgörülü, insana değer veren ve güvenilir olma gibi özellikleri daha fazla önemli görülmüştür. Bu sonuçlara bakarak, kapalı alan aktivite liderlerinin belli kişilik özelliklerine; açık alan aktivite liderlerinin ise becerikli olma gibi davranışsal yönlerini geliştirmeye özen göstermeleri önerilebilir. Dolayısıyla, rekreasyonel liderlik ile ilgili algıların rekreasyonistlerin sosyodemografik göstergelerine göre farklılaştığı söylenebilir. Bu durum, rekreasyonel liderlerin, duruma göre olma yanında, kişiye, gruba ve grup dinamiklerine göre davranmasına işaret etmesi bakımından önemlidir. Rekreasyonistlerin liderlik beklentileri ile ilgili ayrıntılı olarak sunulan bu ipuçlarının rekreasyonel liderlere yol gösterici olması beklenmektedir. Yapılacak başka çalışmalarda, rekreasyonistlerin sahip olduğu kişilik özellikleri ile örtük liderlik algısı arasındaki ilişkilere bakılması ve liderlerin kendilik algılamalarının da belirlenmesi önerilebilir.

\section{KAYNAKÇA}

Ağaoğlu, Y.S. ve Boyacı, M. (2013). Rekreasyon Kavramına Felsefi Yaklaşım, Abant İzet Baysal Üniversitesi Sosyal Bilimler Enstitüsü Dergisi, 13 (2): 1-10.

Büyüköztürk, Ş. (2012). Sosyal Bilimler İçin Veri Analizi El Kitabı İstatistik, Araştırma Deseni SPSS Uygulamaları ve Yorum. (17. Bask1). Ankara: Pegem Yayıncilik.

Calder, B. (1977). An Attribution Theory of Leadership in Behavior. İçinde B. Staw ve J. Salancik (Editörler), New Directions in Organizational (ss. 179-204). Chicago: St. Clair Press.

Danford, H. G. ve Shirley, M. (1970). Creative Leadership in Recreation. Boston: Allyn and Bacon.

Dorfman, P.W., Howell, J.P., Hibino, S., Lee, J.K., Tate, U. ve Bautista, A. (1997). Leadership in Western and Asian Countries: Commonalities and Differences in Effective Leadership Processes Across Cultures, The Leadership Quarterly, 8 (3): 233-274. 
Durmus, B., Yurtkoru, E.S. ve Çinko, M. (2013). Sosyal Bilimlerde SPSS Ze Veri Analizi. İstanbul: Beta Yayıncılık.

Edginton, C.R., Hudson, S.D. ve Ford, P.M. (1999). Leadership in Recreation and Leisure Service Organizations, Illinois: Sagamore Yayıncilik.

Epitropaki, O. ve Martin, R. (2005). From Ideal to Real: A Longitudinal Study of the Role of Implicit Leadership Theories on Leader-Member Exchanges and Employee Outcomes, Journal of Applied Psychology, 90 (4): 659-676.

Epitropaki, O. ve Martin, R. (2004). Implicit Leadership Theories in Applied Settings: Factor Structure, Generalizability, and Stability Over Time, Journal of Applied Psychology, 89 (2): 293-310.

Eroğluer, K. (2014). Örtük Liderlik Üzerine Bir Analiz: İmalat Sektörü Çalışanlarının Kişilik Özelliklerinin Liderlik Algılarına Etkisi, Ege Stratejik Araştırmalar Dergisi, 5 (2): 105-147.

Ewert, A. (1992). Group Development Through Experiential Education: Does It Happen?, Journal of Experiential Education, 15 (2): 56.

Foti, R.J., Fraser, S.L. ve Lord, R.G. (1982). Effects of Leadership Labels And Prototypes on Perceptions of Political Leaders, Journal of Applied Psychology, 67 (3): 326-333.

Gerstner, C.R. ve Day, D.V. (1994). Cross-Cultural Comparison of Leadership Prototypes, The Leadership Quarterly, 5 (2): 121-134.

Green, P. (1981). The Content of a College-Level Outdoor Leadership Course for Land Based Outdoor Pursuits in The Pacific Northwest: A Delphi Consensus (Basılmamış Doktora Tezi). Eugene: University of Oregon.

Hair, J.F., Anderson, R.E., Tatham, R.L. ve William, C. (1998). Multivariate Data Analysis. Beşinci Basım, Upper Saddle River, N. J.: Prentice Hall.

Irwin, C. ve Phipps, M. (1994). The Great Outdoors and Beyond: Common Threads in Leadership Training On Land, inThe Air And in Space, Coalition for Education in The Outdoors Research Symposium Proceedings (ss. 43-52). NY: Cortland.

Jordan, D. (1989). A New Vision for Outdoor Leadership Theory, Leisure Studies, 8 (1): 35-47.

Kalaycı, Ş. (2014). SPSS Uygulamalı Çok Değişkenli İstatistik Teknikleri. Ankara: Asil Yayın Dağıtım.

Karaküçük, S. (2005). Rekreasyon: Boş Zamanları Değerlendirme. Ankara: Gazi Kitabevi.

Keller, T. (1999). Images of The Familiar: Individual Differences and Implicit Leadership Theories, Leadership Quarterly, 10 (3): 590-607.

Koçel, T. (2014). İşletme Yöneticiliği (Yönetim ve Organizasyon, Organizasyonlarda Davranış, Klasik-Modern-Çă̆daş ve Güncel Yaklaşımlar). 14. Baskı. İstanbul: Beta Yayınevi.

Koommoo-Welch, P. (2008). Implicit Leadership Theories: Perceptions of Charisma, People, and Performance. (Basılmamıs Doktora Tezi). North Caroline: North Carolina State University.

Kouzes, J.M. ve Posner, B.Z. (2006). The Leadership Challenge. (Cilt 3). USA: John Wiley and Sons.

Kozak, M.A., Maviş, F., Nergis, H.G. ve Çiçek, D. (2013). Otel İşletmelerinde Yönetim (Fonksiyonel Yaklaşım). Ankara: Detay Yayıncilı.
Kozak, M. (2014). Bilimsel Araştırma: Tasarım, Yazım ve Yayım Teknikleri. Ankara: Detay Yayıncılık.

Kozak, M.A. ve Yüncü, D. (2009). Rekreasyonel Liderlik ve Grup Dinamikleri. İçinde N. Kozak (Editör), Prof. Dr. Fermani Maviş Anı Kitabı (ss. 45-80). Eskişehir: T.C. Anadolu Üniversitesi Yayınları.

Kraus, R.G. (1985). Recreation Program Planning Today. USA: Scott Foresman and Company.

Kraus, R.G. ve Bates, B. J. (1975). Recreation Leadership and Supervision: Guidelines for Professional Development. USA: Saunders.

Ling, W., Chia, R.C. ve Fang, L. (2000). Chinese Implicit Leadership Theory, The Journal of Social Psychology, 140 (6): 729-739.

Little, D.E. ve Watkins, M. (2004). Exploring Variation in Recreation Activity Leaders Experience of Leading, Journal of Park and Recreation Administration, 22 (1): 75-95.

Lord, R.G., Foti, R. J. ve De Vader, C.L. (1984). A Test of Leadership Categorization Theory: Internal Structure, Information Processing, and Leadership Perceptions, Organizational Behavior and Human Performance, 34 (3): 343-378.

Lord, R.G. ve Maher, K.J. (2002). Leadership and Information Processing: Linking Perceptions and Performance. NY: Routledge.

Long, T., Ellis, G., Trunnell, E., Tatsugawa, K. ve Freeman, P. (2001). Animating Recreation Experiences Through Face-To-Face Leadership: Efficacy of Two Models, Journal of Park \& Recreation Administration, 19 (1): 1-22.

Lumpkin, A. (1990). Physical Education and Sport: A Contemporary Introduction. St. Louis: Times Mirror.

Maviş, F. (2006). Otel Yönetimi. Ankara: Detay Yayıncılık.

Morgan, G.A., Leech, N.L., Gloeckner, G.W. ve Barrett, K.C. (2012). IBM SPSS for Introductory Statistics: Use and Interpretation. UK: Routledge.

Mosley, A.L. (1998). A Behavioral Approach to Leadership: Implications for Diversity in Today's Organizations, Journal of Leadership \& Organizational Studies, 5 (1): 38-50.

Myers, J.L., Well, A. ve Lorch, R.F. (2010). Research Design and Statistical Analysis. İngiltere: Routledge.

Neal, M., Finlay, J.L., Catana, G.A. ve Catana, D. (2007). A Comparison of Leadership Prototypes of Arab and European Females, International Journal of Cross Cultural Management, 7 (3): 291-316.

Offermann, L.R., Kennedy, J.K. ve Wirtz, P.W. (1994). Implicit Leadership Theories: Content, Structure, and Generalizability, The Leadership Quarterly, 5 (1): 43-58.

Palmer, D.E. (2009). Business Leadership: Three Levels of Ethical Analysis, Journal of Business Ethics, 88 (3): 525-536.

Paris, L.D. (2004). The Effects of Gender and Culture on Implicit Leadership Theories: A Cross-Cultural Study, Academy of Management Proceedings, B1-B6. Doi:10.5465/ AMBPP.2004.13863009.

Paşa, S.F. (2000). Türkiye Ortamında Liderlik Özellikleri. İçinde Z. Aycan (Editör), Türkiye'de Yönetim ve İnsan Kaynakları Uygulamaları (ss. 225-241). Ankara: Türk Psikoloji Derneği Yayınları. 
Phipps, M. (1984). Group Dynamics in Outdoors: A Model for Teaching Outdoor Leaders, Conference on Outdoor Recreation: A Landmark Conference in The Outdoor Recreation Field (ss. 171-188). Bozeman, Montana.

Powell, W.T. (1923). Recreational Leadership for Church and Community. New York: The Methodist Book Concern.

Priest, S. ve Gass, M.A. (2005). Effective Leadership in Adventure Programming. USA: Human Kinetics.

Pruijt, H. (2002). Social Capital and The Equalizing Potential of the Internet, Social Science Computer Review, 20 (2): 109-115.

Rush, M.C., Thomas, J.C. ve Lord, R.G. (1977). Implicit Leadership Theory: A Potential Threat to The Internal Validity of Leader Behavior Questionnaires, Organizational Behavior and Human Performance, 20 (1): 93-110.

Saruhan, Ş.C. ve Özdemir, A. (2011). Bilim, Felsefe ve Metodoloji. İstanbul: Beta Basım.

Sekaran, U. (1992). Research Methods for Business: A Skill Building Approach, USA: John Wiley\&Sons Inc.

Singer, M. (1990). Implicit Leadership Theory: Are Results Generalizable From Student to Professional Samples?, The Journal of Social Psychology, 130 (3): 407-408.

Stokowski, P.A., Long, P.T. ve Nuckolls, J.S. (1992). Recreation Leadership As a System of Social Ties, Journal of Park and Recreation Administration, 10 (2): 67-77.

Subhash, S. (1996). Applied Multivariate Techniques. Canada: John Wily \& Sons Inc.
Tabak, A., Kızıloglu, A. ve Polat, M. (2010). Türkiye'de Örtülü Liderlik Kuramı: İçeriği ve Yapısı, Çă̆ University Journal Of Social Sciences, 7 (2): 72-86.

Tabak, A., Kızıloğlu, A. ve Türköz, T. (2013). Örtülü Liderlik Ölçeği Geliştirme Çalışması, Middle East Technical University Studies in Development, 40 (1): 97-137.

Tabak, A., Şeşen, H. ve Türköz, T. (2012). Liderlikte Güncel Yaklaşımlar ve Uygulamada Kullanılabilecek Ölçekler. Ankara: Detay Yayincilık.

Tichy, N.M. ve Devanna, M.A. (1990). The Transformational Leader. New York: Wiley.

Torkildsen, G. (2005). Leisure and Recreation Management. İngiltere: Routledge.

Trevino, L.K., Hartman, L.P. ve Brown, M. (2000). Moral Person and Moral Manager: How Executives Develop a Reputation for Ethical Leadership, California Management Review, 42 (4): 128-142.

Türetgen, Ö.İ. ve Cesur, S. (2010). İş Yaşamındaki Yönetici Liderliğe ve Siyasi Liderliğe Yönelik Örtük Liderlik Teorilerinin Karşılaştırılması, Yönetim Dergisi, 21 (67): 52-66.

Van Emmerik, I.H., Euwema, M. C. ve Wendt, H. (2008). Leadership Behaviors Around The World the Relative Importance of Gender Versus Cultural Background, International Journal of Cross Cultural Management, 8 (3): 297-315. 


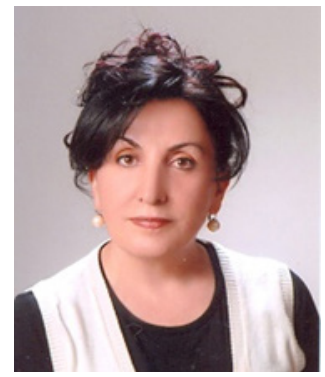

\section{Meryem AKOĞLAN KOZAK}

Ege Üniversitesi, Aydın Turizm İşletmeciliği ve Otelcilik Yüksekokulu'ndan 1980 yılında mezun oldu. 1987 yılında Çukurova Üniversitesi Turizm İşletmeciliği ve Otelcilik YO'da akademik hayata başlayıncaya kadar, TURBAN Urfa Oteli ve bazı özel otellerde yönetici olarak çalıştı. Yüksek lisans derecesini Hacettepe Üniversitesi Turizm İşletmeciliği dalından 1991yılında, doktora derecesini de Gazi Üniversitesi Turizm İşl. Eğitimi dalından 1996 yılında aldı. 1990-1993 yılları arasında Erciyes Üniversitesi Turizm İşlemeciliği ve Otelcilik Yüksekokulu'nda görev yaptı. 1993 yılında Eskișehir MYO'ya geçti. Doçentlik unvanını 1999 yılında Turizm Bilim Dalından aldı. 2005 yılında Anadolu Üniversitesi Turizm ve Otel İșletmeciliği YO'ya 2011 yılında ise İșletme Fakültesi Konaklama Bölümüne profesör olarak atandı. Halen Anadolu Üniversitesi İşletme Fakültesi Konaklama İșletmeciliği Bölümü'nde görev yapmaktadır. Kat Hizmetleri Yönetimi, İnsan Kaynakları Yönetimi, Otellerde Yönetim, Genel Turizm, Temizlik Teknolojileri, Otel Yönetimi, Özel İlgi Turizmi, Turizmde Etik gibi çok sayıda kitabın editör ve yazarıdır. Ayrıca, alanında çok sayıda makale ve bildirisi bulunmaktadır.

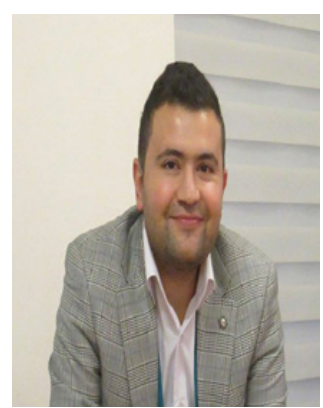

Çağdaş AYDIN

1987 yılında Ankara'da doğdu. İlköğrenimini Ankara'da, Çankaya İlköğretim Okulu ve Özel Büyük Illköğretim Okulunda tamamladı. Lise öğrenimini ise Ankara Ayrancı Lisesinde bitirdi. Üniversite hayatına kadar yaşamını Ankara'da geçirdi. 2010 yılında Muğla Üniversitesi, Muğla Meslek Yüksekokulu, Seyahat İşletmeciliği ön lisans programından mezun oldu. Aynı yıl Muğla Üniversitesinde dikey geçiş yaparak Muğla Meslek Yüksekokulu, Seyahat İșletmeciliği lisans programından mezun oldu. 2013 yılında üniversite yaşamını, üniversite ikincisi olarak tamamladı. Mezuniyetinin hemen arkasından Kastamonu Üniversitesi, Turizm Fakültesine, Araştırma Görevlisi olarak atandı. 2016 yıIında yüksek lisansını tamamladı. Şu an Anadolu Üniversitesi'nde araştırma görevlisi olarak mesleki yaşamını sürdürürken, Turizm İşletmeciliği Ana Bilim Dalı'nda da doktora eğitimine devam etmektedir.

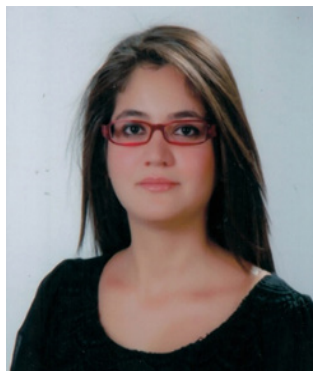

\section{Ceren AYDIN}

1986 yılında Ankara'da doğdu. Ilkkokul, ortaokul ve lise yıllarını Ankara'da geçirdi. Üniversite hayatına 2007 yılında Muğla'da bașladı. 2010 yılında Muğla Meslek Yüksekokulu, Seyahat İşletmeciliği ön lisans programından ikincilikle mezun oldu. Devamında, Dikey Geçiş sınavına girerek Muğla Üniversitesi Seyahat İşletmeciliği lisans programını kazandı. Haziran 2013 yılında Muğla Üniversitesi bünyesinde bulunan tüm fakülte ve yüksekokulları arasından birincilikle mezun oldu. Eylül 2013 yılında Anadolu Üniversitesi Turizm İşletmeciliği Ana Bilim Dalı'nda yüksek lisansa başladı. Şu an Anadolu Üniversitesi Turizm İșletmeciliği Ana Bilim Dalı doktora programında öğrenimine devam etmektedir. 